Supporting information for

\title{
Fabrication of Propeller-Shaped Supra-amphiphile for Construction of Enzyme-Responsive Fluorescent Vesicles
}

Jie Li ${ }^{\text {a }}$, Kaerdun Liu ${ }^{a}$, Yuchun Han ${ }^{b}$, Ben Zhong Tang ${ }^{c^{*}}$, Jianbin Huang ${ }^{a^{*}}$, Yun Yan ${ }^{a^{*}}$

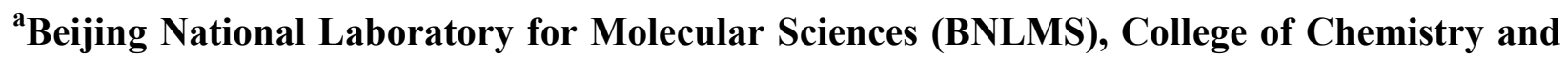
Molecular Engineering, Peking University, Beijing 100871, China

${ }^{b}$ Institute of Chemistry, Chinese Academy of Sciences, Beijing, China

${ }^{c}$ Department of Chemistry, Division of Biomedical Engineering, The Hong Kong University of Science \& Technology, Clear Water Bay, Kowloon, Hong Kong, China

Corresponding Author:

Yun Yan $\quad$ yunyan@pku.edu.cn

Jianbin Huang jbhuang@pku.edu.cn

Ben Zhong Tang tangbenz@ust.hk 
1. The synthetic path of TPE-BPA molecule.

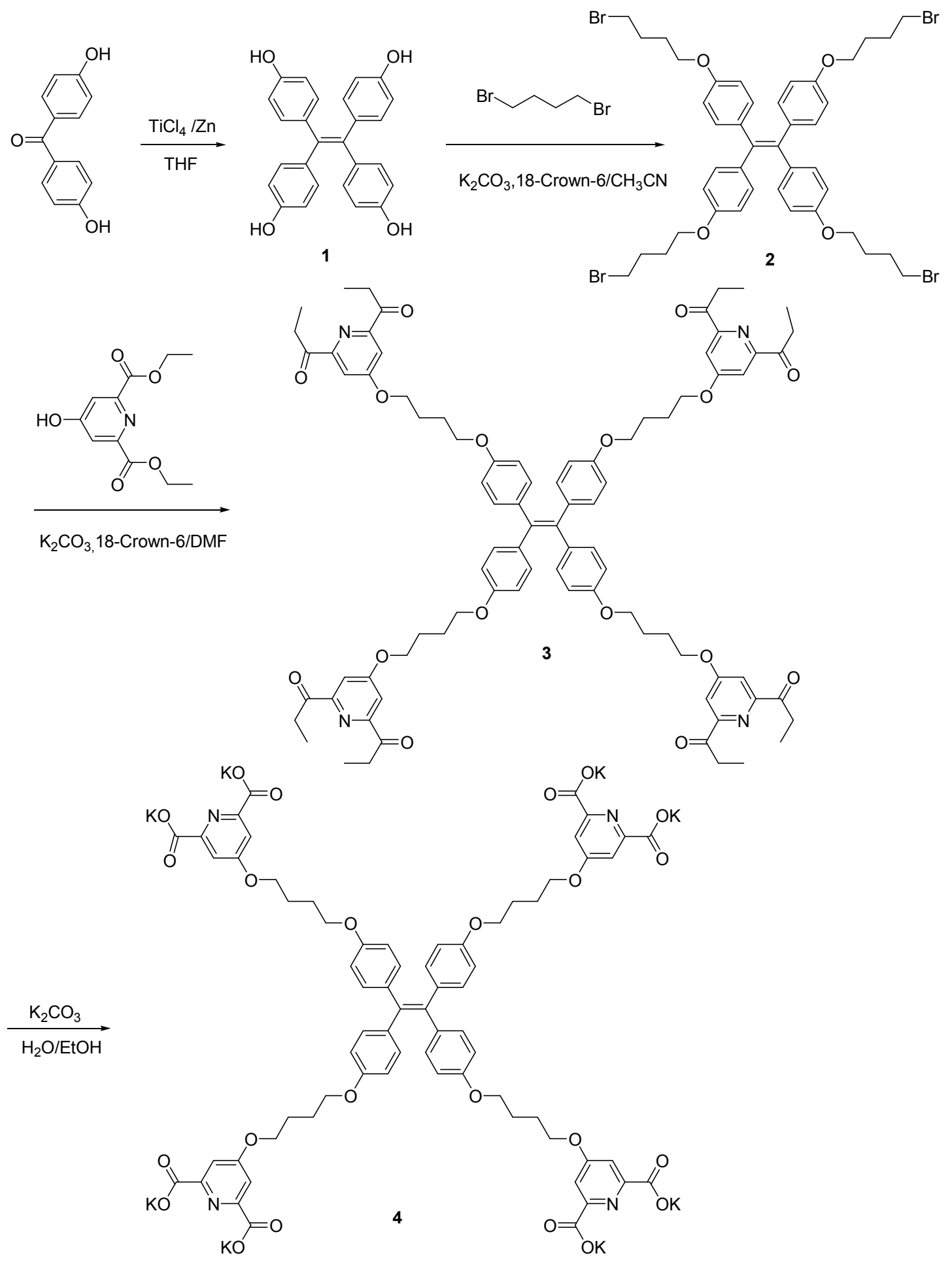


Synthesis of compound 1. Into a $500 \mathrm{~mL}$ flask was dissolved 4,4'-dihydroxybenzophenone $(16.05 \mathrm{~g}, 75 \mathrm{mmol})$ and $\mathrm{Zn}$ dust $(11.78 \mathrm{~g}, 180 \mathrm{mmol})$ in $350 \mathrm{~mL}$ of THF under a $\mathrm{N}_{2}$ atmosphere. The flask was cooled in an acetone-dry ice bath at $-78^{\circ} \mathrm{C}$ and $17.1 \mathrm{~g}(90 \mathrm{mmol})$ of $\mathrm{TiCl}_{4}$ was added carefully. After stirring for $1 \mathrm{~h}$, the reaction mixture was warmed to room temperature and then refluxed overnight. After filtration and solvent evaporation, the product was purified by silica gel column using petroleum ether/ethyl acetate $(3: 1 \mathrm{v} / \mathrm{v})$ as eluent. Compound 1 was obtained as light brown red solid in $89 \%$ yield $(13.2 \mathrm{~g})$.

Synthesis of compound 2. Compound 1(11g, 27.7mmol), 18-crown-6(1.45g, 5.5mmol), and $38.4 \mathrm{~g}$ of $\mathrm{K}_{2} \mathrm{CO}_{3}(0.277 \mathrm{~mol})$ were dissolved in $500 \mathrm{~mL}$ acetonitrile under an Ar atmosphere. Then $0.554 \mathrm{~mol}$ of 1,4-dibromobutane was added, and the mixture was stirred overnight under $70^{\circ} \mathrm{C}$. The reaction mixture was cooled to room temperature and filtered. The solvent was evaporated under vacuum and the crude product was purified by a silica gel column using dichloromethane/petroleum ether $(5: 1 \mathrm{v} / \mathrm{v})$ as eluent. Compound 2 was obtained as yellow solid in $45 \%$ yield (11.6g). ${ }^{1} \mathrm{H}$ NMR (300MHz, $\left.\mathrm{CDCl}_{3}\right), \delta$ (TMS, ppm): 6.926-6.896 (d, 8H), 6.630$6.600(\mathrm{~d}, 8 \mathrm{H}), 3.941-3.901(\mathrm{~m}, 8 \mathrm{H}), 3.499-3.455(\mathrm{~m}, 8 \mathrm{H}), 2.073-2.024(\mathrm{~m}, 8 \mathrm{H}), 1.924-1.877(\mathrm{~m}$, $8 \mathrm{H})$.

Synthesis of compound 3. Compound 2 (1.87g, 2mmol), 18-crown-6 $(0.26 \mathrm{~g}, 1 \mathrm{mmol})$, diethyl 4-hydroxypyridine-2,6-dicarboxylate $(2.3 \mathrm{~g}, 9.6 \mathrm{mmol})$ and $5.54 \mathrm{~g}(40 \mathrm{mmol})$ of $\mathrm{K}_{2} \mathrm{CO}_{3}$ were refluxed in $100 \mathrm{~mL}$ DMF under an Ar atmosphere, and the mixture was stirred overnight under $80^{\circ} \mathrm{C}$. After filtration and solvent evaporation, the product was purified by silica gel column several times using petroleum ether/ethyl acetate $(1: 1 \mathrm{v} / \mathrm{v})$ as eluent. Compound 3 was obtained as yellow solid in $43.6 \%$ yield $(1.37 \mathrm{~g}) .{ }^{1} \mathrm{H} \mathrm{NMR}\left(300 \mathrm{MHz}, \mathrm{CDCl}_{3}\right), \delta(\mathrm{ppm}): 7.778$ (s, 8H), 6.941-6.911(d, 8H), 6.644-6.614 (d, 8H), 4.482-4.435 (m, 16H), 4.208-4.188 (m, 8H), 3.966 $(\mathrm{m}, 8 \mathrm{H}), 2.012-1.972(\mathrm{~m}, 16 \mathrm{H}), 1.477-1.430(\mathrm{t}, 24 \mathrm{H})$. MS-TOF, $\mathrm{C}_{86} \mathrm{H}_{96} \mathrm{~N}_{4} \mathrm{O}_{24}(\mathrm{M}+\mathrm{Na})^{+}: 1591.6$.

Synthesis of compound 4. Compound $3(1.57 \mathrm{~g}, 1 \mathrm{mmol})$ and $1.1 \mathrm{~g}$ of $\mathrm{K}_{2} \mathrm{CO}_{3}$ was dissolved in a 1:1 mixture of ethanol-water. This mixture was stirred overnight under $70^{\circ} \mathrm{C}$. The solution was cooled to room temperature and $\mathrm{HCl}$ solution was then added to precipitate the product. The mixture was filtered, and washed with water several times. The product $(1.24 \mathrm{~g}, 0.888 \mathrm{mmol})$ was dissolved in $\mathrm{KOH}(0.398 \mathrm{~g}, 7.10 \mathrm{mmol})$ water solution. The solvent was evaporated and 
compound 4 was obtained as yellow powder. ${ }^{1} \mathrm{H}$ NMR $\left(300 \mathrm{MHz}, \mathrm{D}_{2} \mathrm{O}\right), \delta(\mathrm{ppm}): 7.407(\mathrm{~s}, 8 \mathrm{H})$, $6.734(\mathrm{~s}, 8 \mathrm{H}), 6.326(\mathrm{~s}, 8 \mathrm{H}), 3.959(\mathrm{~s}, 8 \mathrm{H}), 3.603$ (s, 8H), 1.647 (s, 16H). Elemental analysis: C (45.32\%), $\mathrm{H}(4.44 \%), \mathrm{N}(2.88 \%), \mathrm{C}_{70} \mathrm{H}_{56} \mathrm{~N}_{4} \mathrm{O}_{24} \mathrm{~K}_{8} \cdot 12 \mathrm{H}_{2} \mathrm{O}$.

2. Table S1. Binding constant $\left(\mathrm{K} / \mathrm{M}^{-1}\right)$, Enthalpy $\left(\Delta \mathrm{H}^{\circ} /\left(\mathrm{kJ} \cdot \mathrm{mol}^{-1}\right)\right)$ and binding stoichiometry (n) for $\mathrm{AChCl} / \mathrm{TPE}$ complex in aqueous solution at $\mathrm{T}=25^{\circ} \mathrm{C}$.

\begin{tabular}{|c|c|c|c|c|c|}
\hline \multicolumn{2}{|l|}{ Model } & \multicolumn{2}{l|}{} \\
\hline $\mathrm{K}_{1}(1 / \mathrm{M})$ & $\mathrm{K}_{2}(1 / \mathrm{M})$ & $\Delta \mathrm{H}^{\circ}{ }_{1}(\mathrm{~kJ} / \mathrm{mol})$ & $\Delta \mathrm{H}^{\circ}{ }_{2}(\mathrm{~kJ} / \mathrm{mol})$ & $\mathrm{n}_{1}$ & $\mathrm{n}_{2}$ \\
\hline $2.879 \times 10^{7}$ & $4.082 \times 10^{5}$ & -91.03 & -17.49 & 4.539 & 2.726 \\
\hline
\end{tabular}




\section{Figure S1-S9}

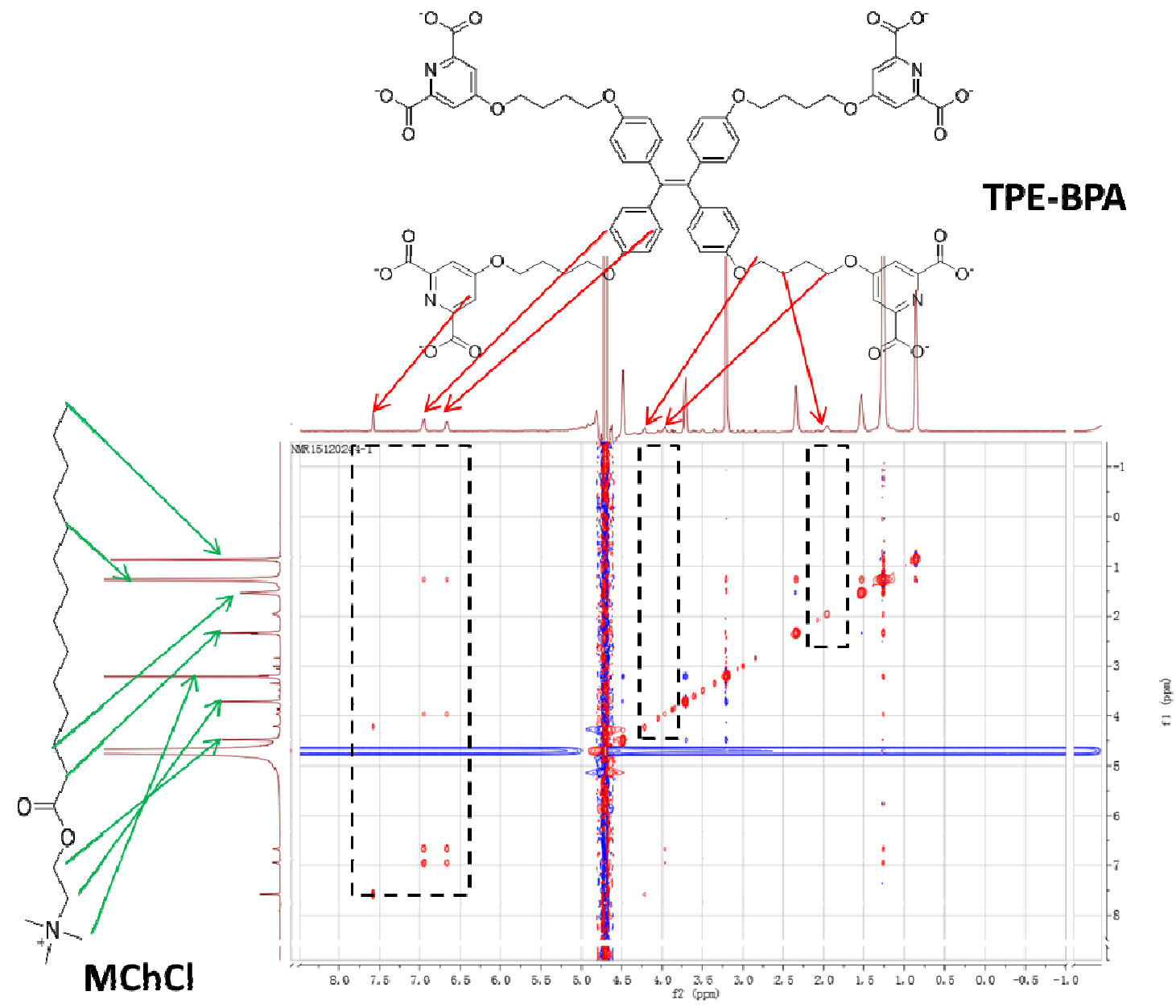

Figure S1. NOE spectra of TPE-BPA@8MChCl vesicles in D2O. Blue areas represent $\mathrm{H}-\mathrm{H}$ correlation in space, and there was no $\mathrm{H}-\mathrm{H}$ correlation in the region of TPE-BPA. This means that there was no interaction between the alkyl chain of $\mathrm{MChCl}$ and alkyl chain of TPE-BPA or tetraphenylethylene part. $[\mathrm{TPE}-\mathrm{BPA}]=2 \mathrm{mM},[\mathrm{MChCl}]=16 \mathrm{mM}$. 


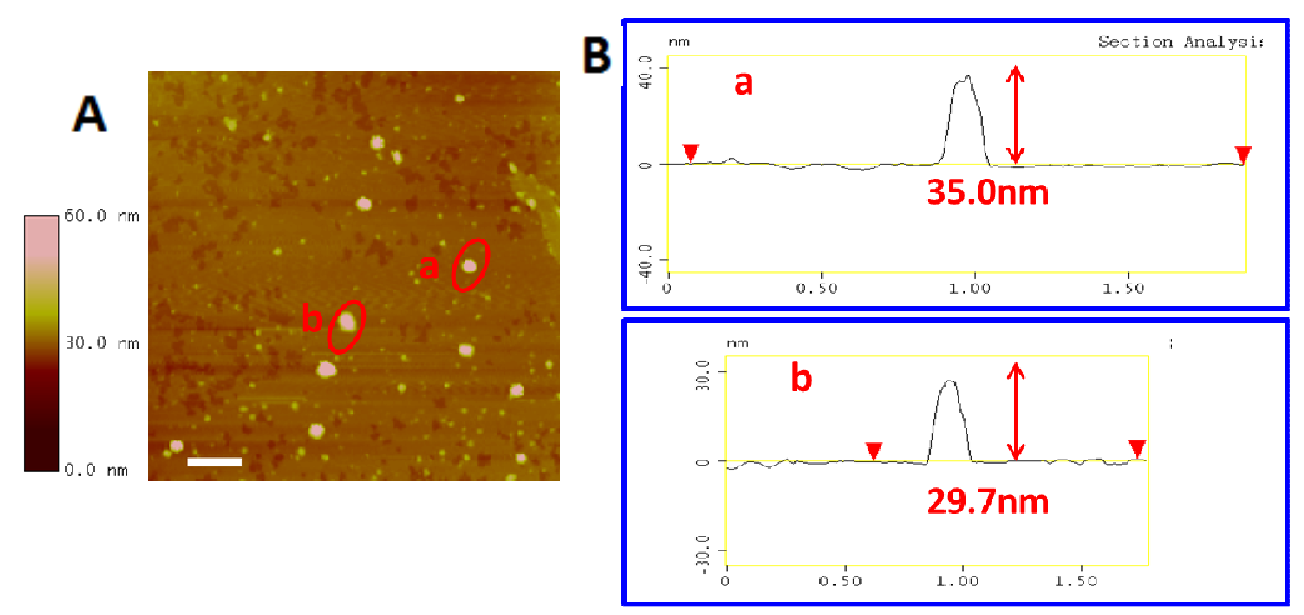

Figure S2. AFM image of the vesicles formed in the TPE-BPA@8MChCl system. [TPE-BPA]= $0.05 \mathrm{mM},[\mathrm{MChCl}]=0.40 \mathrm{mM}$. The height profile in panel $\mathbf{B}$ reveals collapsed thickness of the vesicles is 35.0 and $29.7 \mathrm{~nm}$, respectively. The extending length of TPE-BPA is $2.5 \mathrm{~nm}$, so that the numbers of the shells in these vesicles are $35 / 2.5 / 2=7$ and $29.7 / 2.5 / 2=6$, respectively. 

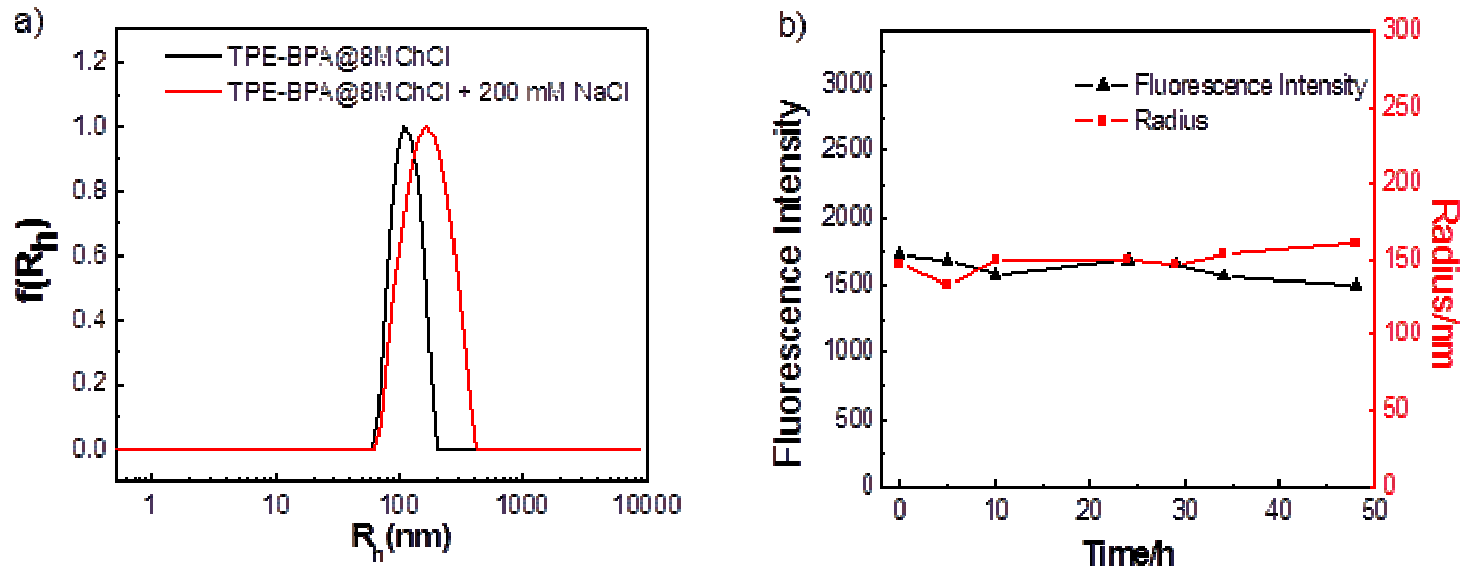

Figure S3. (a) DLS result of TPE-BPA@8MChCl system with and without $200 \mathrm{mM} \mathrm{NaCl}$. (b) Real-time size and fluorescence intensity variation of the TPE-BPA@8MChCl vesicles in PBS buffer $(\mathrm{pH}=7.4)$ at $25^{\circ} \mathrm{C}$. [TPE-BPA $]=0.05 \mathrm{mM},[\mathrm{MChCl}]=0.40 \mathrm{mM}$.

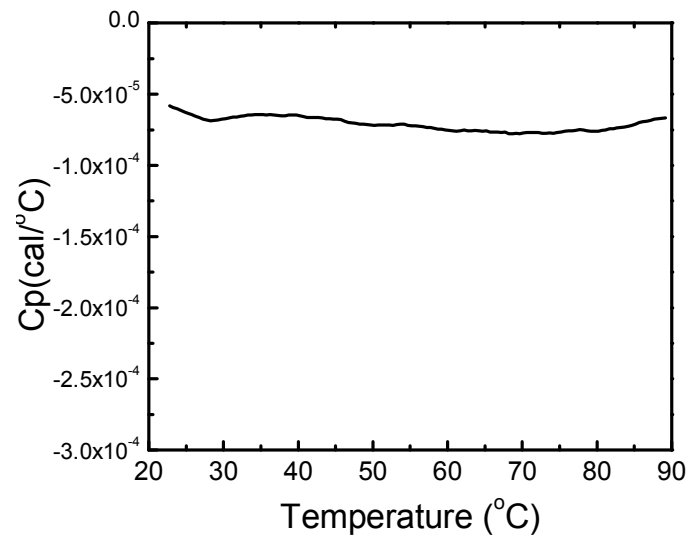

Figure S4. DSC result for the vesicles formed in the TPE-BPA@8MChCl system. [TPE-BPA]= $0.05 \mathrm{mM},[\mathrm{MChCl}]=0.40 \mathrm{mM}$. 

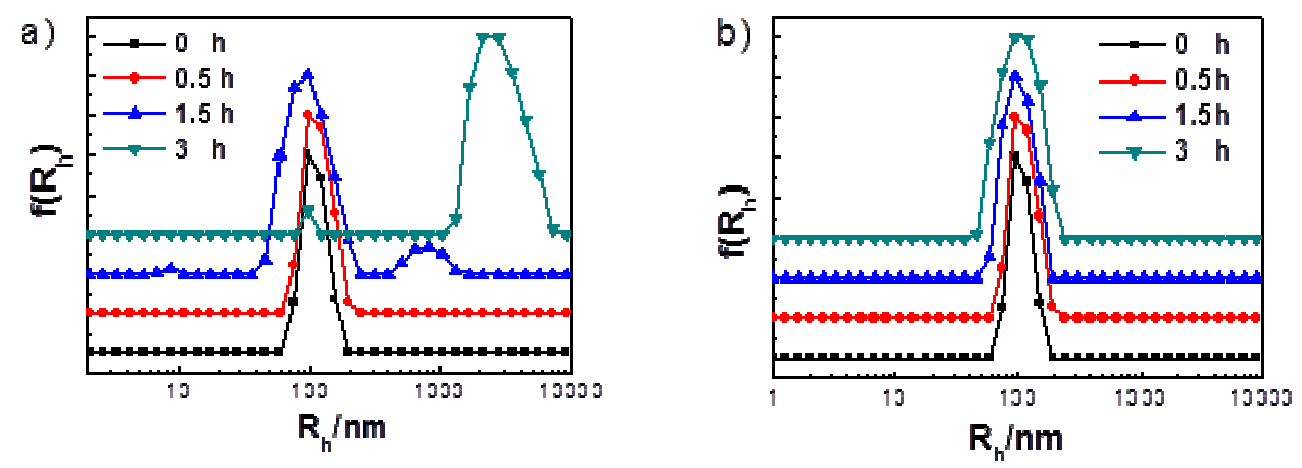

Figure S5. The real-time DLS results of the TPE-BPA@8MChCl vesicles with (a) 1U/mL AChE and (b) without AChE. The DLS results demonstrated that the size of vesicle was hardly changed without AChE, while a new peak with an average radius of $750 \mathrm{~nm}$ occurred after AChE was added in 1.5 hours. The average radius gradually increased to $3 \mu \mathrm{m}$ within 3 hours, suggesting a gradual disassembly of the vesicles induced by enzyme. The increase in the average radius is probably due to the generation of insoluble mystric acid by the enzymatic reaction. [TPE-BPA $]=0.05 \mathrm{mM},[\mathrm{MChCl}]=0.40 \mathrm{mM} . \mathrm{T}=25^{\circ} \mathrm{C}$
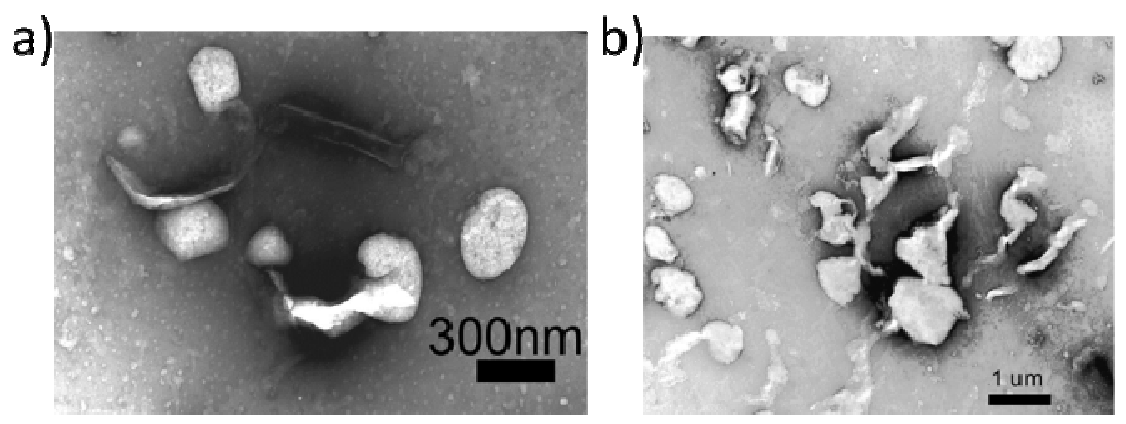

c)
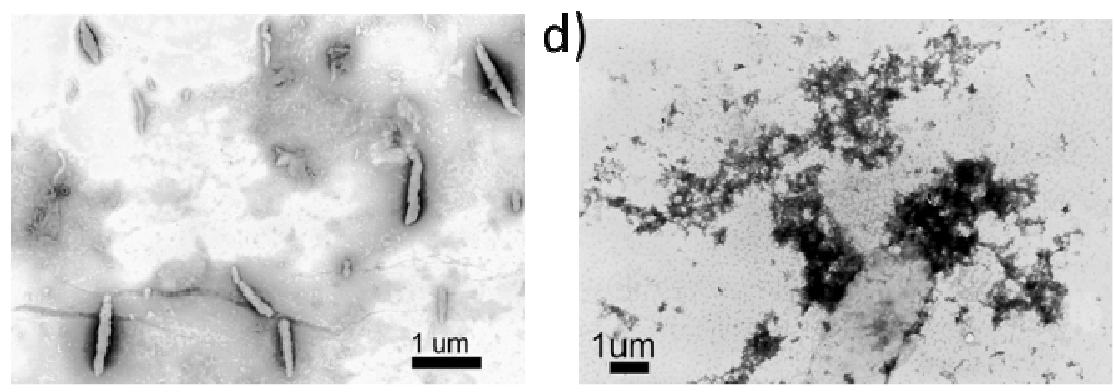

Figure S6. TEM observation for the time revolution of the TPE-BPA@8MChCl vesicles upon addition of $1 \mathrm{U} / \mathrm{mL}$ AChE. Images are corresponding to (a) $0.5 \mathrm{~h}$, (b) $1.5 \mathrm{~h}$, (c) $3 \mathrm{~h}$ and (d) $24 \mathrm{~h}$, respectively. $[\mathrm{TPE}-\mathrm{BPA}]=0.05 \mathrm{mM},[\mathrm{MChCl}]=0.40 \mathrm{mM} . \mathrm{T}=25{ }^{\circ} \mathrm{C}$. 

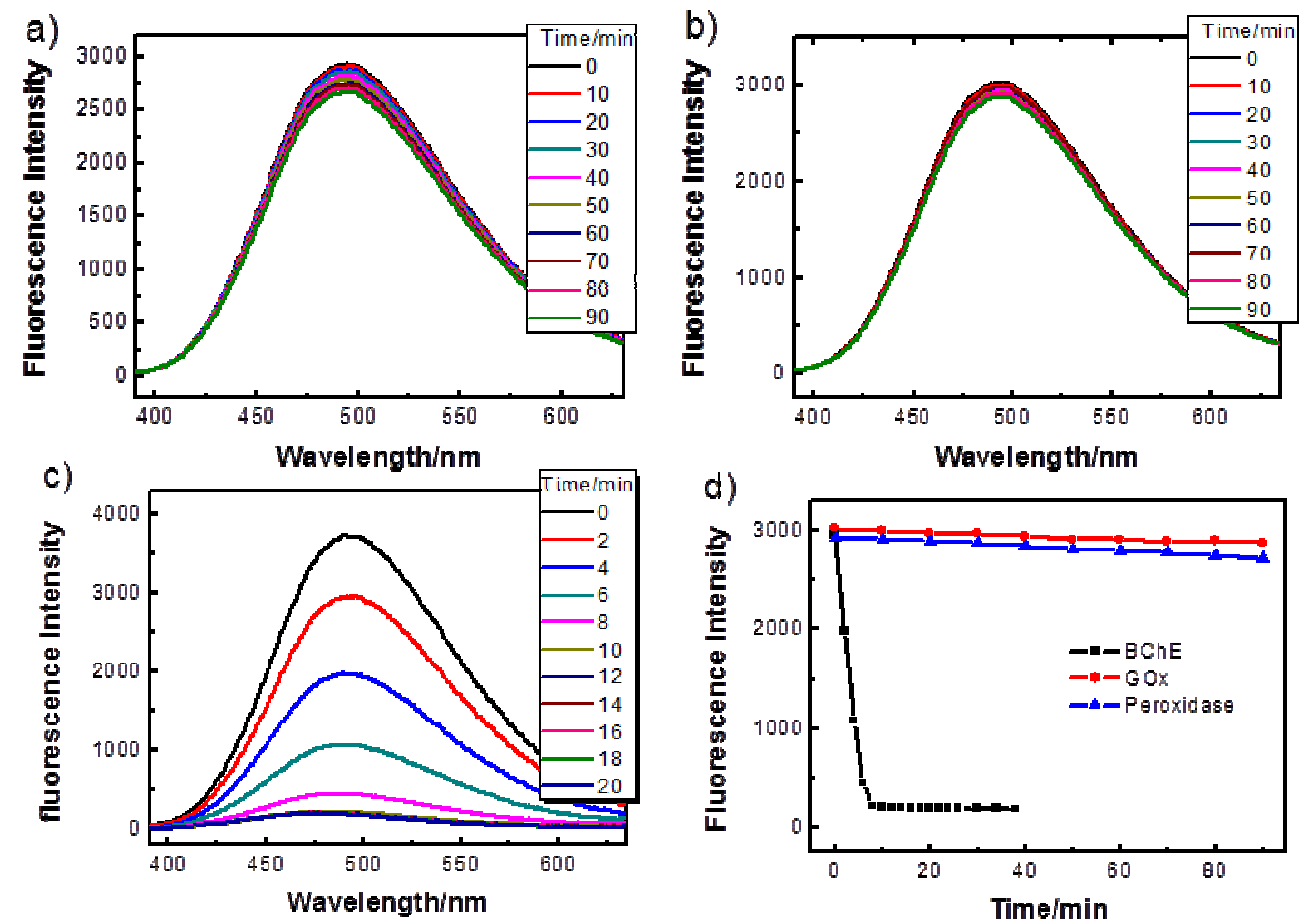

Figure S7. The fluorescence measurement for the TPE-BPA@8 $\mathrm{MChCl}$ vesicles in the presence of $1 \mathrm{U} / \mathrm{mL}$ (a) Peroxidase, (b) Glucose Oxidase X, (c) BChE. (d) is the real-time fluorescence decay curves for the above systems. $[\mathrm{TPE}-\mathrm{BPA}]=0.05 \mathrm{mM},[\mathrm{MChCl}]=0.40 \mathrm{mM}, \mathrm{T}=25^{\circ} \mathrm{C}$ 


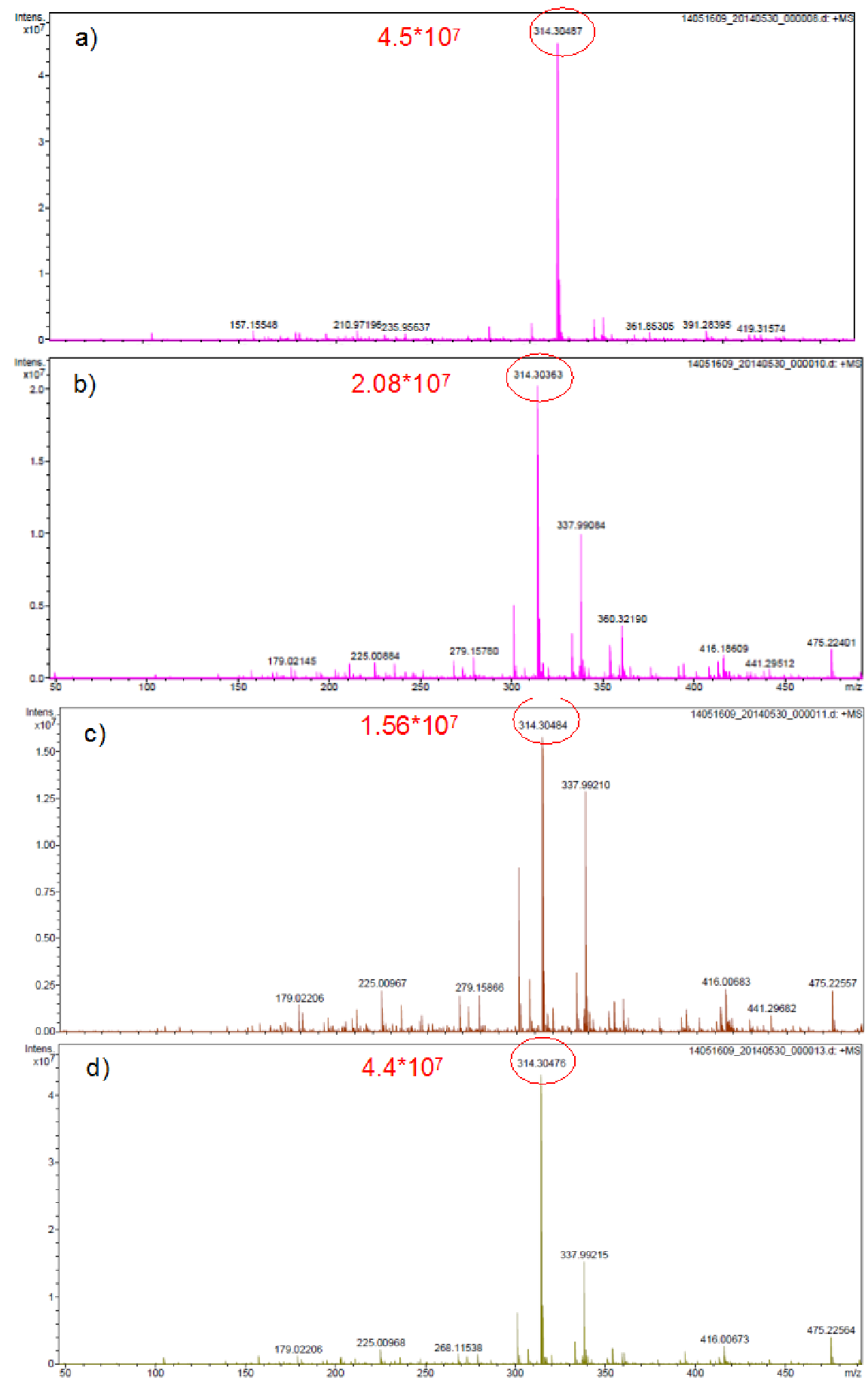

Figure S8. $\mathrm{MS}$ results for the $\mathrm{MChCl}$ and $\mathrm{TPE}$ solutions with and without $\mathrm{AChE}$. The measurements were made in the presence of $1 \mathrm{U} / \mathrm{ml} \mathrm{AChE} \mathrm{within} \mathrm{(a)} 0 \mathrm{~h}$, (b) $4 \mathrm{~h}$, and (c) $6 \mathrm{~h}$. (d) Control experiment for the system without AChE within 6 hours. It is clear that the situation of $0 \mathrm{~h}$ and that for the enzyme free system is almost the same. [TPE-BPA] $=0.05 \mathrm{mM}$, $[\mathrm{MChCl}]=0.40 \mathrm{mM}$. 


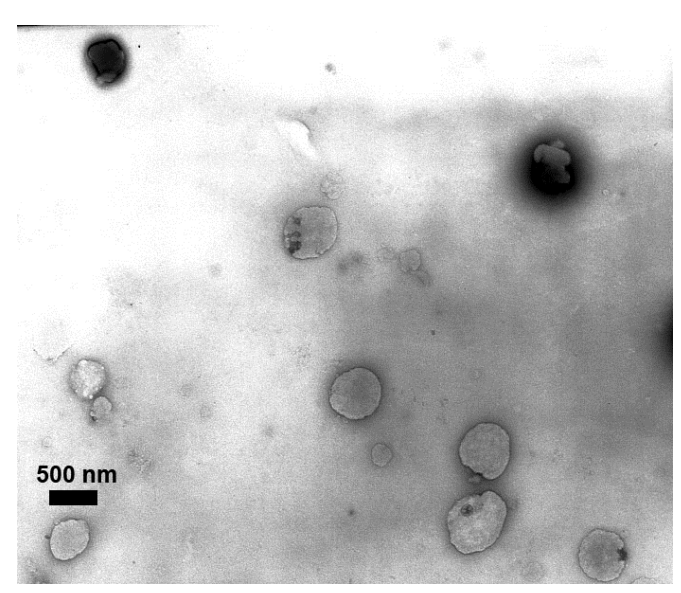

Figure S9. The TEM image of tacrine-loaded vesicles after addition of $5 \mathrm{U} / \mathrm{mL}$ enzyme AChE for 2 hours. $[\mathrm{TPE}-\mathrm{BPA}]=0.05 \mathrm{mM},[\mathrm{MChCl}]=0.40 \mathrm{mM} . \mathrm{T}=25^{\circ} \mathrm{C}$ 